\title{
Sperm numbers, sperm storage duration and fertility limitation in the Odonata
}

\author{
Klaus Reinhardt \\ Department of Animal and Plant Sciences, University of Sheffield, \\ Sheffield S10 2TN, UK. <k.reinhardt@sheffield.ac.uk> \\ and
} Behavior, Ecology, Evolution and Systematics Section, Department of Biological Sciences, Illinois State University, Normal, IL - 61790-4120, USA.

Key words: Odonata, dragonfly, sperm age, sperm longevity, sperm number.

\section{ABSTRACT}

The status of the Odonata as a model taxon for studying the evolution and diversity of reproductive behaviours is shown here to have declined relative to crickets and Drosophila. Very few available data on ejaculate size, the number of sperm stored by females and the duration of sperm storage reveal poor knowledge of these areas in the Odonata. Some observations tentatively suggest that species without direct sperm removal transfer larger numbers of sperm. Observations on the fertilization success of eggs laid by sexually isolated females and the temporal variation in paternity were used to assess the longevity of the sperm population in the female. The generality of the claim that female odonates have full fecundity after a single mating can not be upheld. In addition, it is not clear whether any possible decrease in fertilization ability in isolated females is due to decreasing sperm quantity or quality. Costs and benefits of sperm longevity, sperm storage and multiple mating are discussed for both sexes. It is proposed that mating frequency and sperm storage duration may be linked in the Odonata. Testable predictions and ideas related to sperm biology are put forward in which odonates may be used to address general questions of evolutionary biology.

\section{INTRODUCTION}

Central to evolutionary biology is the variation in fitness between individuals, an issue that is tightly linked to the evolution of polyandry which, in turn, is connected to areas such as the host-parasite coevolution and sexual selection. For the latter, the Odonata have, for many years, been the taxon of choice, mainly so because of their unique and diverse modes of sperm competition and their territoriality (e.g. Corbet 1999: 427-558, 2003). This may have slowed down: When I quickly searched for papers in the commonly used literature database 'Web of Science' $<$ http://wos.mimas.ac.uk/> published in three successive periods the proportion of articles on sexual selection using crickets and fruitflies increased while that on the Odonata remained at a similar (and low) level (Table 1). This decline is worrying 
Table 1. Articles on sexual selection published in international journals that are listed in the electronic data base 'Web of Science' and their proportion using Odonata, crickets (Gryllidae) and fruitflies (Drosophila) as study organisms. The number of papers on the respective taxon were counted from a list appearing from search words "Insect OR cricket / Drosophila / Odonata AND sexual selection". They were compared to the number of articles with the search word "sexual selection".

Period Articles on sexual selection

1991-1995

1996-2000

2001-2003
1,231

2,126

1,513
Proportion of all articles (\%) using Odonata Gryllidae Drosophila

0.89

0.85

2.76

6.50

8.89

0.86
5.13

6.40
11.04

as the opposite should be expected: All papers published in 'Odonatologica', a journal entirely devoted to the study of Odonata entered the database only in 1997. This relative decline indicates that odonates have lost importance in the exciting field of sexual selection (but see Corbet 2003; Córdoba-Aguilar et al. 2003 for different opinions), perhaps the difficult rearing of odonates prevents laboratory-based work more easily carried out in crickets and fruitflies. However, it is also possible that previous research in the Odonata has not been sufficiently exploited and promoted to maintain them as a model system. For example, predictions on fitness outcomes are commonly based on the widely available information on sperm volume (reviewed by Córdoba-Aguilar et al. 2003) during copulatory stages. We know little about the relationship between ejaculate volume and sperm number (but see e.g. Siva-Jothy 1988; Watanasit 1997). This may have hampered any considerations on sperm numbers and, moreover, sperm quality which is recognized increasingly as an important fitness predictor (see e.g. Snook 2005). Furthermore, it becomes increasingly clear in insects that ejaculates are not homogenous in terms of sperm quality (Reinhardt \& Siva-Jothy 2005), which also downweighs the importance of sperm volume. It is perhaps a curiosity that in a model taxon for sperm competition very few studies have studied sperm in detail (but see e.g. Åbro 1999, 2000, 2003) or even employed a protocol to actually count sperm (but see e.g. Siva-Jothy 1988). Likewise, it does not appear to be well investigated whether the sperm transferred during one mating is sufficient to fertilize a female's lifetime production of eggs (Córdoba-Aguilar et al. 2003). This may again be a matter of quality and quantity - a small number of long-lived sperm may be more important than many short-lived sperm. In order to encourage approaches that consider the number and quality of individual sperm I gathered observations on sperm numbers transferred to, or stored by, female odonates, as well as the duration of sperm storage in the female. It appears that in the Odonata we lack even basic data in these areas despite their lack being clearly mentioned by Miller (1995) and Fincke (1997). I will re-iterate and refine some of them because their easy testability in the odonates hopefully stimulates further research and, thus, promotes odonatology as a scientific field. 


\section{Methods}

Sperm numbers

Data on the number of sperm transferred during mating and the mechanism of sperm removal were extracted from the literature. If the latter information was unavailable, the genitalia morphology was used as a proxy (see Waage 1986; Miller 1987; Siva-Jothy 1988 for a reasoning). Additional data on sperm numbers were collected in central Illinois, USA during July and August 2001. The examination procedure followed standard techniques (e.g. Siva-Jothy 1988) and involved killing of the specimen by decapitation and the removal of the sperm storage organ. It was placed into a defined volume (usually 1 or $1.5 \mathrm{ml}$ ) of insect saline. After homogenization e.g. by drawing the solution a few times through a pipette the sample can be analysed, with one prior dilution step, if necessary. A drop of the solution is placed onto a haemocytometer and the number of sperm counted under $x 400$ magnification.

\section{Duration of sperm storage}

Female insects fertilize their eggs at the moment of oviposition (Wigglesworth 1972). Hence, the period between mating and oviposition can be used to assess sperm storage and sperm longevity. The decline of sperm numbers in the female sperm storage organ is known as sperm depletion. I extracted such data from the literature. Presently, three methods are used to investigate the sperm storage duration in insects. The maximum storage duration corresponds to minimum sperm longevity. In one method, females are mated once and kept sexually isolated. The proportion of fertile eggs over time is examined. It is also possible to monitor the number of viable sperm in the spermatheca at discrete time intervals after the female was sexually isolated. A third possibility is the study of temporal variation in paternity of doubly-mated females which reveals for how long the sperm of a particular male contributes to paternity. To put sperm storage durations in perspective I gathered data on the lifespan of females, where possible.

\section{Number of SPERM Delivered by MALES}

Pantala bymenea (Say) - I found 1.33 million sperm (mean of three counts) in the seminal vesicle of one male. If in this species the complete sperm population of the seminal vesicle is transferred to the penis vesicle for a mating, this number represents the maximum ejaculate size of this male.

The whole vesicle content is emptied during a mating in Celithemis elisa and Sympetrum rubicundulum (Waage 1984) and the majority of males in several zygopteran species (Miller 1987, 1995; Cordero \& Miller 1992; Cordero et al. 1995) whereas in Nesciothemis farinosa (Miller 1984) it is used for several matings. Examples of sperm numbers in two other species are given in Table 2. I conclude that the numbers of sperm stored by the male before and after intra-male sperm translocation is insufficiently known. 
Table 2. Literature data on the numbers of sperm transferred by males and sperm numbers stored by field-collected females.

\begin{tabular}{|c|c|c|}
\hline $\begin{array}{l}\text { Number of sperm stored by female } \\
\text { Species }\end{array}$ & Reference & $\begin{array}{l}\text { Likely mode of } s \\
\text { competition }\end{array}$ \\
\hline Xanthagrion erythroneurum Selys & & \\
\hline $\begin{array}{l}\quad 86-198,000(n=11) \\
\text { Comphus externus Hagen in Selys }\end{array}$ & Watanasit (1997) & Removal \\
\hline $\begin{array}{l}203,500 \\
\text { Comphus graslinellus Walsh }\end{array}$ & Reinhardt (2003) & Partial removal? \\
\hline $\begin{array}{l}968,550 \\
\text { Crocothemis erythraea (Brullé) }\end{array}$ & Reinhardt (2003) & Removal \\
\hline max. 47 mio in spermatheca & Siva-Jothy (1984) & Packing \\
\hline $\begin{array}{l}2.22 \text { mio sperm in male vesicle } \\
\text { Orthetrum cancellatum (Linnaeus) }\end{array}$ & Siva-Jothy (1988) & \\
\hline mean ejaculate size: 308 mio $(n=9)$ & Siva-Jothy (1984) & Removal \\
\hline
\end{tabular}

\section{NUMBER OF SPERM STORED BY FEMALES}

Anax junius (Drury) - no sperm were found in a female captured on 28 July 2001 at foraging flight. The small size of spermatheca (diameter $1.5 \mathrm{~mm}$ ) and the large amount of an unidentified granulous material found in the spermatheca indicated it was perhaps a virgin female.

Celithemis eponina (Drury) - a female captured 28 July 2001 had stored a mean of 10,300 sperm. Within the spermatheca sperm were found to be condensed at the ends of the spermathecal sacs.

Libellula luctuosa Burmeister - three females were caught on 28 July 2001 and kept alive in the laboratory. Upon examination on 2 August 2001 the following sperm numbers were found: zero, 71,000 and 68,000 . The sperm was immobile but possibly alive.

Tramea lacerata Hagen - a presumably old female with heavy wing wear captured 17 July 2001 had stored a mean of 10 million sperm; her ovary yielded approximately 1,880 eggs. The sperm was not organized in bundles.

Data on three further species are given in Table 2. Little information is available on the amount of sperm used to fertilize a complete clutch of eggs. Watanasit (1997) showed that female Xanthagrion erythroneurum Selys have, on average, 158,000 fewer sperm in the spermatheca than before oviposition. This is $72 \%$ of the sperm numbers found in freshly mated females (Watanasit 1997). I conclude that sperm numbers stored by field-collected females are poorly known.

\section{SPERM LIMITATION}

Sperm limitation is the process where due to repeated mating the male runs out of sperm (as opposed to sperm depletion in females). Only one such case in the odonates is known so far. In Plathemis lydia (Drury) an "immature" male mating to 
10 females in succession produced infertile clutches in the females after his seventh and his ninth mating (Jacobs 1955). This is indicative but not conclusive as it is not clear whether it was a shortage of the number of sperm that caused the reduction in female fertility. Adult males under normal conditions produce egg hatchabilities in $92 \%$ of the copulations. This figure decreased to $70 \%$ if the male mating rate was experimentally increased (Jacobs 1955).

A mating Perithemis tenera (Say) male produced infertility in females from his 43rd mating onwards, another on his 15 th mating at one day, but no observable infertility in a further 85 matings during the next seven days. The third explicitly mentioned male mated 101 times in eight days, only the 103rd mating (on day 9) resulted in an egg batch with no hatching at all (Jacobs 1955).

No data are available for the costs to produce so many ejaculates. Jacobs (1955) noted, however, that after 20 matings $P$. lydia males became less active and were easily driven away by rival males. A similar situation was found in P. tenera, although one male mated 127 times in six successive days. I conclude that sperm limitation is not well investigated in the Odonata but was negligible in two frequently mating libellulids. Costs of ejaculate production are unknown in the Odonata.

\section{DURATION OF SPERM STORAGE BY FEMALES}

Mnais pruinosa Selys - Siva-Jothy \& Tsubaki (1989) showed sperm of two males being alive for at least eight days.

Enallagma cyathigerum (Charpentier) - females of this species live on average 16 days (Cordero 1994). P.L. Miller (in Corbet 1999: 495) stated that sperm of this species is active in the male seminal vesical for 10 days (see also Miller 1982).

Enallagma hageni (Walsh) - two-day old sperm contributed to fertilization of eggs (Fincke 1984).

Ischnura elegans (Vander Linden) - Miller's (1987) and Cooper's et al. (1996) data suggest sperm to be viable for $7,8,9$ and 23 days. One female produced infertile eggs 11 and 12 days after (her third) mating.

Ischnura graellsii (Rambur) - Cordero's (1990) and Cordero \& Miller's (1992) study showed that sperm of males contributed to fertilization 4-29 days after " 1 or 2 copulations" (Cordero 1991). The strongest drop in fertility happened at day 16 , reaching $50 \%$ at around day 20 . Females of this species only live 11 days in the laboratory, on average (Cordero 1994), and in the field have a daily survival rate of $85 \%$ such that only $1 \%$ of the females live longer than 16 days after their first mating Cordero (1990).

Ischnura ramburii (Selys) - Sirot \& Brockmann (2001) stated that some females “... laid over 2000 fertilized eggs up to 21 days after their single mating” perhaps implying that females laid exclusively fertile eggs. Mean female lifespan in their study varied from 9 to 12 days such that for most females sperm transferred during one mating is sufficient for lifetime. Maximum female lifespans in their study were 23 days and one out of 18 females laid a small sterile clutch the 19 th day after her single mating. 
Ischnura senegalensis (Rambur) - Sawada (1998) found sperm viable 5, 6 and 7 days after mating (not investigated thereafter).

Ischnura verticalis Say - in one female, Grieve (1937) observed hatching from eggs that were fertilized with 30 days old sperm. Fincke's (1987) data indicate that sexually isolated females "oviposited and matured eggs over the two-week period" after isolation.

Xanthocnemis zelandica (McLachlan) - Rowe (1987) mentions that a "single copulation can provide sufficient sperm for many egg batches, probably for life" (p. 85), "based on females which laid several egg batches in the laboratory ca 2-3 days apart" (p. 89). No data are provided.

Anax parthenope Selys - Hadrys et al. (1993) report that eggs were fertilized 50 hours after a mating. No information is available for eggs laid thereafter.

Gomphus externus Hagen in Selys - the sperm stored by one female captured in copula was mobile three days after sexual isolation (Reinhardt 2003).

Gomphus graslinellus Walsh - the sperm stored by one female captured at postovipository rest was viable (fertilized eggs) though not mobile after 4 days of storage (Reinhardt 2003).

Hemicordulia australiae (Rambur) - Rowe (1987) states that "a single copulation is probably sufficient to inseminate a female for life". No data are presented for this suggestion and female lifespan.

Procordulia grayi (Selys) - Rowe (1987) mentions that an old female kept in captivity "... still produced fertile eggs six days after her first mating".

Erythemis simplicicollis (Say) - until day 12 after the last insemination a female still laid fertile eggs. The mean time between mating and oviposition after which seven females still laid fertile eggs was 6.2 days. Two females showed a severe reduction in hatching success $(<20 \%) 6$ and 12 days after mating, respectively (McVey \& Smittle 1984). However, up to 13 clutches were fertilized.

Nannophya pygmaea Rambur - in three females Siva Jothy \& Tsubaki (1994) report sperm viabilities of at least 4 days. No information is available beyond these dates. Females of this species live on average 16 days (Tsubaki \& Ono 1986).

Sympetrum danae (Sulzer) - Michiels's (1992) study demonstrated paternity contributions by males nine days after mating. Then the experiment was terminated. The paternity data suggested possible sperm viabilities of up to 25 days. This corresponds to female lifespan in the field (Michiels \& Dhondt 1989).

In conclusion, six studies quantified sperm storage duration for a substantial part of a female's life, two (McVey \& Smittle 1984; Miller 1987), possibly three (Sirot \& Brockmann 2001) indicated evidence for a reduction in fertility some time after mating. It is unknown whether this due to sperm quantity or sperm quality. Two experiments, one by Cordero (Cordero 1990, 1991; Cordero \& Miller 1992) and another by Sirot \& Brockman (2001), demonstrate that a single mating provides a female odonate with sufficient sperm supply. Both experiments come from the same genus, Ischnura. Most researchers will agree that this idea should be tested for a range of further taxa, body sizes and mating systems. 


\section{Discussion}

Fertility limitation - sperm quantity or quality?

Females continuing to lay eggs without a sufficient quantity or quality of sperm show a decline in the proportion of fertilised eggs. There is some evidence for a decline in the proportion of fertilised eggs but this does, in general, not allow to conclude whether fertilization ability is limited by sperm numbers or sperm quality. Fertility may be limited because (1) the life of sperm cells is short, (2) sperm numbers are used up by fertilization, or (3) sperm passively leak from the female genital tract (Gilbert 1981; Tsubaki \& Yamagashi 1991; Reinhardt et al. 1999). Observations in the Odonata may help to elucidate this question: While female Orthetrum sabina (Drury) and Pantala flavescens (Fabricius) interrupted egg laying, when their sperm supply in the spermathecal ducts or bursae was low, one $O$. sabina and one $O$. taeniolatum female continued and consequently laid infertile eggs (Miller \& Miller 1989). A number-related decline in fertility is likely in Ischnura verticalis because females remated when their sperm supply was artificially restricted by interrupted copulations (Fincke 1987). However, it has to be considered that the higher sperm density in females of the non-interrupted treatment might decrease sperm motility and, therefore, increase sperm longevity (see Bolton \& Havenhand 1996). Another caveat is the possibility that males vary in the sperm age demography of their ejaculates. Testing whether the fertility decreases simply due to low numbers of sperm or because of an accelerated sperm death at lower sperm densities would be at the forefront of reproductive biology.

As the present study shows care has to be taken when assessing sperm longevity. While paternity studies compare the average lifespan (or competitiveness) of two sperm populations, the fertilization monitoring compares the maximum lifespan. Given the trade-off between sperm swimming speed and sperm lifespan (Bolton \& Havenhand 1996) it is possible that more competitive (more mobile) sperm are shorter lived. Testing this idea in odonates would bring large credits to odonatology; one hint to its existence comes from salmon (Gage et al. 2004).

\section{Variability in ejaculate size}

In insects, ejaculate sizes vary enormously (e.g. in grasshoppers Reinhardt 2001; Reinhardt \& Arlt 2003) with several factors such as male condition and mating history, female status, the number of competitors, or sex ratio (reviewed in Simmons 2001). The question of how flexible males are in their ejaculatory decisions is completely unaddressed in the Odonata. Across species, it is possible that smaller ejaculate sizes occur in direct sperm removers, although that is not true for in Orthetrum cancellatum (Linnaeus) (Table 2). It would be possible to test this prediction by comparing the ejaculate size of phylogenetic sister taxa that differ in their mode of sperm removal (e.g. Calopteryx, Ischnura). However, more relevant to evolutionary biologists would be whether males within a species that employ different reproductive tactics differ in sperm numbers transferred. 
Age-related variability in ejaculate quality - sperm age and ageing

The age of sperm that males deliver may also vary. The data in McVey \& Smittle (1984) suggested variation in sperm viability across females. P.L. Miller (in McVey \& Smittle 1984) put forward the hypothesis that the storage duration of sperm in the seminal vesicle of males before transfer might account for the large difference in sperm viability across females (McVey \& Smittle 1984). His hypothesis remained untested to date. Recent work on Drosophila (Snook \& Hosken 2004) indicated that sperm viability is indeed an important factor in sperm competition. Moreover, theoretical (Siva-Jothy 2000) and empirical work (Reinhardt \& SivaJothy 2005) indicate a strong influence of sperm age on male and female fitness, i.e., beyond the simplified dead-live dichotomy of sperm. Because in the odonates, sperm cells may age in two different compartments after release from the testes it is possible to easily manipulate sperm age by preventing sperm transfer of males just after their intra-male sperm translocation. Because intra-male sperm translocation occurs just prior to copulation (Corbet 1999: 495), Miller's hypothesis can be specified to predict that sperm are shorter lived in the penis vesicle than in the primary genitalia of the ninth abdominal segment. If a high mating frequency enables a rapid use of penis sperm, long-term storage in the seminal vesicle of the ninth segment and hence, intra-male sperm translocation, may not be necessary. Two studies mention intra-male sperm translocation to occur just after copulation (Robey 1975; Reinhardt 1998). The latter explicitly stated a high mating activity at the site. The mating rate may, therefore, high and the sperm stored only briefly in the penis vesicle. Contrary to this suggestion is an observation in the Zygoptera. Cordero et al. (1995) observed in the laboratory that males not copulating after intra-male sperm translocation did not transfer sperm again for matings one day later. Miller (1995: 59) explicitly pointed out a difference between Anisoptera and Zygoptera. In contrast to Enallagma cyathigerum in which males keep sperm in their penis vesicles alive for 10 days but cannot empty their sperm vesicle (Miller 1995), male anisopterans can expel their sperm in the absence of a female by muscular compression of the vesicle.

The repeated mating between the same male and female pair (Wildermuth 2004) is another example which suggests that the transfer or more freshly produced sperm might be favourable as the interaction between the same male and female cannot be interpreted as sexual selection.

Genotypic variability in ejaculate quality

- defence versus offence function of the ejaculate

Two selection pressures are suggested to act on males regarding their ejaculates, (1) to protect their ejaculate in the female: "ejaculate defence function", and (2) to prevent the fertilization by rival males: "ejaculate offence function" (Rice 2000; Simmons 2001). At the moment no plausible mechanism is known of how accessory gland fluids in the ejaculate of a male can attack a rival's male sperm but not his own. An offense function of the ejaculate would predict that the mixture of the ejaculate of two males has a shorter longevity in the female spermatheca than two ejaculates of the same male. By contrast, if males were selected for an ejaculate defense function, for which there is some evidence from Drosophila (Rice 2000), 
no such decreased sperm longevity should be found in mixed ejaculates. Siva-Jothy (1997) suggested that sperm bundles, or spermatodesms (Omura 1955, 1957; Hadrys \& Siva-Jothy 1994; Abro 1999, 2000, 2003) may help to increase the longevity of individual sperm cells within the bundle by sacrificing some sperm of a bundle to either ejaculatory substances by rival males or substances by females. By contrast, Åbro (2000) suggested a nutritional function of the substance that holds the sperm cells together which would possibly mean an increased sperm longevity. Males of territorial species - with a probably higher mating frequency - deliver free sperm whereas non-territorial species delivered sperm bundles (Siva-Jothy 1997). This supports the idea that males are selected to increase sperm longevity. However, it is unknown whether this increased sperm longevity benefit applies only in the presence of other males' ejaculates.

Conflict between males and females over the duration of sperm storage

Males and females may be in an evolutionary conflict over the storage of sperm with regard to male genotype (see Córdoba-Aguilar et al. 2003). However, because both sexes also benefit if the lifespan of sperm exceeds the period between mating and the subsequent fertilization (e.g. Ridley 1988) it may lead the sexes to co-operate. Several of these benefits still await empirical testing. Males may benefit from producing long-living sperm by retaining a share of fertile sperm in the spermatheca for a large part of the female's life. Yet, male and female contributions to sperm longevity are unknown in most organisms. In Orthetrum coerulescens (Fonscolombe) sperm collected from the spermatheca was actively moving in saline whereas sperm from the bursa copulatrix was not (Miller 1990). This suggests that the female produces substances that inactivate sperm motility and thereby possibly prolong sperm longevity.

Females may benefit from increased sperm longevity in a number of ways. By keeping sperm viable in the storage organs females can avoid re-mating which, in a number of insects (Arnqvist \& Nilsson 2000; Crudgington \& Siva-Jothy 2000; Stutt \& Siva-Jothy 2001) is detrimental to the female. Sperm storage enables females to postpone fertilization after mating when males are scarce or absent, for example in forest-dwelling species or when colonizing a new location. A fruitful start might be to test whether females of pioneer species or those of low density and therefore low sexual encounters have increased sperm longevity.

\section{Costs of sperm storage}

Previously not considered reasons for female remating are possible high costs of sperm storage. Female insects need to allocate ressources to produce proteins that assist in sperm storage (e.g. Neubaum \& Wolfner 1999). Allocating resources to sperm storage may compete with and lower other reproductive functions (Roth \& Reinhardt 2003). Presently, we lack any further test of the costs of resource allocation to sperm storage. The correlation between low mating frequency, long lifespan and elaborated sperm storage tissue in the Corduliidae and the Aeshnidae (Midttun 1976; Siva-Jothy 1987), and the rather short lifespan, high mating frequency and lack of storage tissue in the Libellulidae (Siva-Jothy 1987) indicate that Odonata may be very useful objects to investigate costs of sperm storage. 
Another possible costs of sperm storage could arise if sperm quality declines during the storage process. Fitness consequences of female insects using aged sperm do not show consistent results (Stockley \& Simmons 1998; Reinhardt et al. 1999; Seal 2000; Simmons 2001; Snook \& Hosken 2004). Odonates with a direct sperm removal mechanism could be very useful in assessing the effect of sperm quality, especially in the calopterygids in which hand-pairing can be used (Oppenheimer \& Waage 1987). Groups of females with and without the delivery of fresh sperm that is with and without removal of aged sperm through hand-pairing - can be compared in their fertilization pattern. Such an experiment would address the question whether females benefit from sperm competition or not - an important contribution of odonatology to evolutionary biology.

\section{Costs of multiple mating to female odonates}

Mating rates for most odonates are high (Fincke 1997) and could potentially be related to transferring and using fresh sperm. To my knowledge, no study has investigated the costs of multiple mating to female odonates. One that looked at some of its aspects did not produce consistent results (Sirot \& Brockman 2001). Several studies suggested male coercion of females as a cause of multiple mating by females, so-called convenience polyandry (Cordero \& Andrés 2002; but see Fincke 1997 for a different view) but its costs remain unknown. Hence, it remains fruitful to investigate whether females that mate multiply have a lower (or higher) lifespan or reproductive output than females that mate once. Without such studies it is difficult to balance the costs of multiple mating against the costs of sperm storage and to disentangle what is cause and what is consequence. Females that cannot avoid additional matings when they arrive at the oviposition site are predicted to reduce investment into sperm storage. Alternative to reducing investment in sperm storage it is likewise possible that low costs of matings to females prevent selection on females to store sperm alive for a long time. As a result, male coercion or convenience polyandry may actually represent "voluntary" remating by females. Either way a positive correlation between female mating frequency and sperm longevity is predicted. From the few available data (Table 2) the possible sperm depletion in isolated females of the frequently mating species Erythemis simplicicollis (McVey \& Smittle 1984) supports this notion whereas the sperm depletion in the less frequently mating species Ischnura elegans (Miller 1987) does not; see also the correlation between mating frequencies, lifespan and the occurrence of specialized secretory cells in the female sperm stores in corduliids, aeshnids and libellulids mentioned above.

\section{CONCLUSIONS}

Taxa such as Ischnura, Calopteryx or the Libellulidae with a diversity of mating systems may prove useful candidates to investigate the proportional degree of male and female contribution to sperm longevity in relation to the cost of production long-lived sperm, the cost of sperm storage to females, female mating frequency and the mechanism of sperm precedence. Since odonates show a large degree of variability in these parameters they should be suitable study subjects. If the 
odonates can serve as a prime group to address such general questions on the physiological mechanisms of sperm transfer and storage they could regain some of their importance in the study of reproductive biology and evolutionary ecology. Given the enormous influence that some of these questions have for the evolution of mating systems, for gene flow and speciation it is likely that these questions become more rather than less important.

\section{ACKNOWLEDGEMENTS}

Steffen Hahn, Jens Rolff and Yannick Moret critically read the manuscript. I also wish to thank the reviewers Adolfo Cordero and Ola Fincke for many but not necessarily agreeing comments. Parts of this study were supported by a FeodorLynen Fellowship of the Alexander von Humboldt-Foundation (Bonn).

\section{REFERENCES}

Åbro, A., 1999. The size range of sperm bundles in aeshnid dragonflies.

Odonatologica 28: 273-277.

Åbro, A, 2000. Sperm clusters in Zygoptera (Coenagrionidae, Lestidae, Calopterygidae). Odonatologica 29: 51-56.

Åbro, A., 2003. The composition of sperm bundles in Aeshna juncea (L.) (Anisoptera: Aeshnidae). Odonatologica 32: 153-157.

Arnqvist, G. \& T. Nilsson, 2000. The evolution of polyandry: multiple mating and female fitness in insects. Animal Behaviour 60:145-164.

Bolton, T.F. \& J.N. Havenhand, 1996. Chemical mediation of sperm activity and longevity in the solitary ascidians Ciona intestinalis and Ascidiella aspersa.

Biological Bulletin 190: 329-225.

Cooper, G., P.W.H. Holland \& P.L. Miller, 1996. Captive breeding of Ischnura elegans (Vander Linden): observations on longevity, copulation and oviposition (Zygoptera: Coenagrionidae). Odonatologica 25: 261-273.

Corbet, P.S., 1999. Dragonflies: behaviour and ecology of Odonata. Harley Books, Colchester.

Corbet, P.S., 2003. Reproductive behaviour of Odonata: the history of a mystery. International Journal of Odonatology 6: 185-193.

Cordero, A., 1990. The adaptive significance of the prolonged copulations of the damselfly, Ischnura grael/sii (Odonata: Coenagrionidae). Animal Behaviour 40: 43-48.

Cordero, A., 1991. Fecundity of Ischnura graellsii (Rambur) in the laboratory (Zygoptera: Coenagrioniae). Odonatologica 20: 37-44.

Cordero, A., 1994. The effect of sex and age on survivorship of adult damselflies in the laboratory (Zygoptera: Coenagrionidae). Odonatologica 23: 1-12.

Cordero, A. \& J.A. Andrés, 2002. Male coercion and convenience polyandry in a calopterygid damselfly. Journal of Insect Science 2.14 <http://insectscience.org/2.14>.

Cordero, A. \& P.L. Miller, 1992. Sperm transfer, displacement and precedence in Ischnura graellsii (Odonata: Coenagrionidae). Behavioral Ecology and Sociobiology 30: 261-267.

Cordero, A., S. Santolamazza-Carbone \& C. Utzeri, 1995. Male disturbance, repeated insemination and sperm competition in the damselfly Coenagrion scitulum (Zygoptera: Coenagrionidae). Animal Behaviour 49: 437-449. 
Córdoba-Aguilar, A., E. Uhía \& A. Cordero Rivera, 2003. Sperm competition in Odonata (Insecta): the evolution of female sperm storage and rivals' sperm displacement. Journal of Zoology 261: 381-398.

Crudgington, H.S. \& N.T. Siva-jothy, 2000. Genital damage, kicking and early death. Nature 407: 855-856.

Fincke, O.M., 1984. Sperm competition in the damselfly Enallagma hageni (Odonata: Coenagrionidae): benefits of multiple mating to males and females. Behavioral Ecology and Sociobiology 14: 235-240.

Fincke, O.M., 1987. Female monogamy in the damselfly Ischnura verticalis Say (Zygoptera: Coenagrionidae). Odonatologica 16: 129-143.

Fincke, O.M., 1997. Conflict resolution in the Odonata: implications for understanding female mating patterns and female choice. Biological Journal of the Linnean Society 60: 201-220.

Gage, M.J.G., C.P. MacFarlane, S. Yeates, R.G. Ward, J.B. Searle \& G.A. Parker, 2004. Spermatozoal traits and sperm competition in Atlantic salmon: relative sperm velocity is the prmary determinant of fertilization success. Current Biology 14: 44-47.

Gilbert, D.G., 1981. Ejaculate esterase 6 and initial sperm use by female Drosophila melanogaster. Journal of Insect Physiology 27: 641-650.

Grieve, E.G., 1937. Studies on the biology of the damselfly Ischnura verticalis Say, with notes on certain parasites. Entomologica Americana 17: 121-153.

Hadrys, H., B. Schierwater, S.L. Dellaporta, R. Desalle \& L.W. Buss, 1993. Determination of paternity in dragonflies by random amplified polymorphic DNA fingerprinting. Molecular Ecology 2: 79-87.

Hadrys, H. \& M.T. Siva-Jothy, 1994. Unravelling the components that underlie insect reproductive traits using a simple molecular approach. In: Schierwater, B., B. Streit, G.P. Wagner \& R. DeSalle (eds) "Molecular ecology and evolution: approaches and applications", Birkhäuser, Basel, pp. 75-90.

Jacobs, M.E., 1955. Studies on territorialism and sexual selection in dragonflies. Ecology 36: 566-586.

McVey, M.E. \& B.J. Smittle, 1984. Sperm precedence in the dragonfly Erythemis simplicicollis. Journal of Insect Physiology 30: 619-628.

Michiels, N.K., 1992. Consequences and adaptive significance of variation in copulation duration in the dragonfly Sympetrum danae. Behavioral Ecology and Sociobiology 29: 429-433.

Michiels, N.K. \& A.A. Dhondt, 1989. Effects of emergence characteristics on longevity and maturation in the dragonfly Sympetrum danae (Anisoptera: Libellulidae). Hydrobiologia 171: 149-158.

Midttun, B., 1976. The morphology of the spermatheca, bursa copulatrix and vagina of Somatochlora arctica (Zetterstedt) (Odonata: Corduliidae). Norwegian Journal of Zoology 24: 175-183.

Miller, P.L., 1982. The occurrence and activity of sperm in mature female Enallagma cyathigerum (Charpentier) (Zygoptera: Coenagrionidae). Odonatologica 11: 159-161.

Miller, P.L., 1987. Sperm competition in Ischnura elegans (Vander Linden) (Zygoptera: Coenagrionidae). Odonatologica 16: 201-207.

Miller, P.L., 1990. Mechanism of sperm removal and sperm transfer in Orthetrum coerulescens Fabr. (Odonata: Libellulidae). Physiological Entomology 15: 199-208.

Miller, P.L., 1995. Dragonflies. Richmond, Slough, UK.

Neubaum, D.M. \& M.F. Wolfner, 1999. Wise, winsome, or weird? Mechanisms of sperm storage in female animals. Current Topics in Developmental Biology 41: 67-97. 
Omura, T., 1955. A comparative study of the spermatogenesis in the Japanese dragonflies. I. Family Libellulidae. Biological Journal of Okoyama University 2: 95-135.

Omura, T., 1957. A comparative study of the spermatogenesis in the Japanese dragonflies. II. Families Aeschnidae, Gomphidae, and Calopterygidae. Biological Journal of Okoyama University 3: 1-85.

Oppenheimer, S.D. \& J.K. Waage, 1987. Hand-pairing: a new technique for obtaining copulations within and between Calopteryx species (Zygoptera: Calopteraygidae).

Odonatologica 16: 291-296.

Reinhardt, K., 1998. Reproductive behaviour of Leucorrhinia albifrons (Burmeister) in a nonterritorial situation (Anisoptera: Libellulidae). Odonatologica 27: 201-211.

Reinhardt, K., 2001. Determinants of ejaculate size in a grasshopper. Behavioral Ecology and Sociobiology 50: 503-510.

Reinhardt, K., 2003. Aspects of the reproductive behaviour and physiology of three North American Gomphidae species (Anisoptera). Notulae Odonatologicae 6: 4-8.

Reinhardt, K. \& D. Arlt, 2003. Ejaculate size variation in the migratory locust, Locusta migratoria. Behaviour 140: 319-332.

Reinhardt, K. \& M.T. Siva-Jothy, 2005. An advantage for young sperm in the house cricket, Acheta domesticus. The American Naturalist 165: in press.

Reinhardt, K., G. Köhler \& J. Schumacher, 1999. Females of the grasshopper Chorthippus parallelus (Zett.) do not remate for fresh sperm. Proceedings of the Royal Society of London (Series B: Biological Sciences) 266: 2003-2009.

Rice, W.R., 2000. Dangerous liaisons. Proceedings of the National Academy of Sciences of the USA 97: 12953-12955.

Ridley, M., 1988. Mating frequencies and fecundity in insects. Biological Reviews of the Cambridge Philosophical Society 63: 509-549.

Robey, C.W., 1975. Observations on the breeding behavior of Pachydiplax longipennis (Odonata: Libellulidae). Psyche 82: 89-96.

Roth, S. \& K. Reinhardt, 2003. Facultative sperm storage in response to nutritional status in a female insect. Proceedings of the Royal Society of London (Series B: Biological Sciences) 270: S54-S56.

Rowe, R.J., 1987. The dragonflies of New Zealand. Auckland University Press, New Zealand.

Sawada, K., 1998. Sperm precedence in the damselfly 1schnura senegalensis (Rambur): is prolonged copulation advantageous to sperm precedence? (Zygoptera: Coenagrionidae). Odonatologica 27: 425-431.

Seal, N.J., 2000. The effect of sperm storage and timing of mating on offspring sex ratios in the yellow dung fly Scatophaga stercoraria. Ecological Entomology 25: 357-361.

Simmons, L.W., 2001. Sperm competition and its evolutionary consequences in the insects. Princeton University Press, Princeton, USA.

Sirot, K.L. \& H.J. Brockmann, 2001. Costs of sexual interactions to females in rambur's forktail damselfly, Ischnura ramburi (Zygoptera: Coenagrionidae). Animal Behaviour 61: 415-424.

Siva-Jothy, M.T., 1987. The structure and function of the female sperm-storage organs in libellulid dragonflies. Journal of Insect Physiology 33: 559-567.

Siva-Jothy, M.T., 1988. Sperm 'repositioning' in Crocothemis erythraea, a libellulid dragonfly with a brief copulation. Journal of Insect Behavior 1: 235-245.

Siva-Jothy, M.T., 1997. Odonate ejaculate structure and mating systems. Odonatologica 26: 415-437.

Siva-Jothy, M.T., 2000. The young sperm gambit. Ecology Letters 3: 172-174. 
Siva-Jothy, M.T. \& Y. Tsubaki, 1989. Variation in copulation duration in Mnais pruinosa pruinosa Selys (Odonata: Calopterygidae). 1. Alternative mate securing tactics and sperm precedence. Behavioral Ecology and Sociobiology 24: 39-45.

Siva-Jothy, M.T. \& Y. Tsubaki, 1994. Sperm competition and sperm precedence in the dragonfly Nannophya pygmaea. Physiological Entomology 19: 363-366.

Snook, R.R., 2005. Sperm in competition: not playing by the numbers. Trends in Ecology and Evolution 20: 46-53.

Snook, R.R. \& D.j. Hosken, 2004. Sperm death and dumping in Drosophila. Nature 428: 939-941.

Stockley, P. \& L.W. Simmons, 1998. Consequences of sperm displacement for female dungflies. Proceedings of the Royal Society of London B 265: 1755-1760.

Stutt, A.D. \& M.T. Siva-Jothy, 2001. Traumatic insemination and sexual conflict in the bed bug Cimex lectularius. Proceedings of the National Academy of Sciences of the USA 98: 5683-5687.

Tsubaki, Y. \& T. Ono, 1986. Competition for territorial sites and alternative mating tactics in the dragonfly Nannophya pygmaea (Odonata: Libellulidae). Behaviour 97: 234-252.

Tsubaki, Y. \& M. Yamagashi, 1991. "Longevity" of sperm within the female of the melon fly, Dacus cucurbitae (Diptera: Tephritidae), and its relevance to sperm competition. Journal of Insect Behavior 4: 243-250.

Waage, J.K., 1984. Sperm competition and the evolution of odonate mating systems. In: Smith, R.L. (ed.) "Sperm competition and the evolution of odonate mating systems", Academic Press, New York, pp. 251-290.

Waage, J.K., 1986. Evidence for widespread sperm displacement ability among Zygoptera (Odonata) and the means for predicting its presence. Biological Journal of the Linnean Society 28: 285-300.

Watanasit, S., 1997. Sperm displacement in the damselfly, Xanthagrion erythroneurum (Zygoptera: Coenagrionidae) - variance in female sperm count and genital morphology. Journal of the Science Society of Thailand 23: 115-122.

Wigglesworth, V.B., 1972. The principles of insect physiology. Chapman Hall, London.

Wildermuth, H., 2004. Sequenzielle Mehrfachpaarung beim gleichen Vierfleckpaar (Libellula quadrimaculata) - Zufall oder Gesetzmäßigkeit? Tagungsband 23. Jahrestagung der Gesellschaft Deutschsprachiger Odonatologen (GdO), 19.-21.03.2004 in Oldenburg, p. 16. 